\title{
Sulfur Reduction at Hyperthermoacidophilic Conditions with Mesophilic Anaerobic Sludge as the Inoculum
}

\author{
Adrian Hidalgo-Ulloa, Irene Sánchez-Andrea, Cees Buisman, and Jan Weijma* \\ Cite This: Environ. Sci. Technol. 2020, 54, 14656-14663 \\ Read Online
}

ABSTRACT: Sulfur reduction at hyperthermoacidophilic conditions represents a promising opportunity for metal sulfide precipitation from hot acidic metallurgical streams, avoiding costly cooling down. The suitability of mesophilic anaerobic sludges as the inoculum for sulfurreducing bioreactors operated at high temperature and low $\mathrm{pH}$ was explored. We examined sludges from full-scale anaerobic reactors for sulfur-reducing activity at $\mathrm{pH} 2.0-3.5$ and 70 or $80{ }^{\circ} \mathrm{C}$, with $\mathrm{H}_{2}$ as an electron donor. At $\mathrm{pH} 3.5$ in batch experiments, sulfidogenesis started

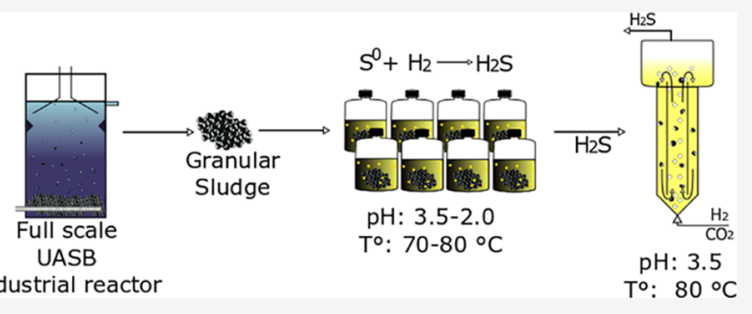
within 4 days, reaching up to $100-200 \mathrm{mg} \cdot \mathrm{L}^{-1}$ of dissolved sulfide produced after 19-24 days, depending on the origin of the sludge. Sulfidogenesis resumed after removing $\mathrm{H}_{2} \mathrm{~S}$ by flushing with nitrogen gas, indicating that sulfide was limiting the conversion. The best performing sludge was used to inoculate a $4 \mathrm{~L}$ gas-lift reactor fed with $\mathrm{H}_{2}$ as the electron donor, $\mathrm{CO}_{2}$ as the carbon source, and elemental sulfur as the electron acceptor. The reactor was operated in semibatch mode at a $\mathrm{pH} 3.5$ and $80{ }^{\circ} \mathrm{C}$, and stable sulfide production rates of $60-80 \mathrm{mg} \cdot \mathrm{L}^{-1} \cdot \mathrm{d}^{-1}$ were achieved for a period of 24 days, without formation of methane or acetate. Our results reveal the potential of mesophilic anaerobic sludges as seed material for sulfur-reducing bioprocesses operated at hyperthermoacidophilic conditions. The process needs further optimization of the volumetric sulfide production rate to gain relevance for practice.

\section{INTRODUCTION}

Hydrogen sulfide $\left(\mathrm{H}_{2} \mathrm{~S}\right)$ reacts with divalent chalcophile metal ions resulting in precipitation of metal sulfides (eq 1 ), which can be used to remove dissolved metal ions such as $\mathrm{Cu}^{2+}$ and $\mathrm{Zn}^{2+}$ from aqueous streams. Metal sulfide precipitation has several advantages compared to the still commonly used hydroxide precipitation, such as lower residual metal concentrations and generation of denser and thus less voluminous sludge with better dewatering characteristics. ${ }^{1}$ Moreover, the use of sulfide allows selective precipitation when more than one metal is present. ${ }^{2}$

$$
\mathrm{H}_{2} \mathrm{~S}_{(\mathrm{aq})}+\mathrm{Me}_{(\mathrm{aq})}^{2+} \rightarrow \mathrm{MeS}_{(\mathrm{s})}+2 \mathrm{H}_{(\mathrm{aq})}^{+}
$$

Sulfidogenic processes mediated by microorganisms that target sulfate as the terminal electron acceptor are already applied on an industrial scale. ${ }^{3,4}$ Sulfate-reducing bacteria (SRB) use a wide variety of electron donors, achieving conversion rates in bioreactors of $10-30 \mathrm{~g} \mathrm{SO}_{4}{ }^{2-} \mathrm{L}^{-1} \cdot \mathrm{d}^{-1}$ at circumneutral $\mathrm{pH}^{5-10}$ and temperatures from $30-65{ }^{\circ} \mathrm{C}$. However, metallurgical streams are often acidic (2-4) and hot $\left(65-80{ }^{\circ} \mathrm{C}\right),{ }^{9,11}$ which appears incompatible with existing sulfate reduction technologies. ${ }^{6}$ Moreover, sulfate-reducing microorganisms that thrive at (hyper)thermoacidophilic conditions have not been identified to the best of our knowledge, even though mesophilic-acidophilic and thermophilic-neutrophilic sulfate reducers have been isolated. ${ }^{2-5,9,12-14}$
Elemental sulfur has also been proposed as a sulfur source for biological sulfidogenesis. ${ }^{15}$ Under mesophilic conditions and at circumneutral $\mathrm{pH}$, sulfur reduction rates of $0.5-3.0 \mathrm{~g} \mathrm{~S}$. $\mathrm{L}^{-1} \cdot$ day $^{-1}$ can be achieved with electron donors such as acetate, glucose, or mixed organics in bioreactors of various design. ${ }^{13,16-18}$ Although, hyperthermoacidophilic sulfur reducers are commonly isolated from natural environments where high temperature and acidic conditions are predominant (e.g., volcanic areas and thermal waters), ${ }^{12,19,20}$ it has not been investigated for its potential for high-rate sulfide generation. Sulfur reduction at hyperthermoacidophilic conditions represents an interesting microbiological opportunity, as it would allow an all-in-one process for base metal (e.g., copper) recovery from hot and acidic metallurgical streams like those generated during hydrometallurgical gold processing. ${ }^{15}$ Furthermore, operating sulfur reduction processes at low $\mathrm{pH}$ offers the potential for selective metal recovery from wastewater and process streams laden with multiple metals, ${ }^{21}$ as metal sulfide solubility is greatly affected by $\mathrm{pH}^{22}$ This is an appealing

Received: April 22, 2020

Revised: October 9, 2020

Accepted: October 20, 2020

Published: November 2, 2020

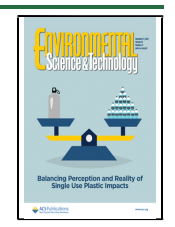


option for the metallurgical industry as it results in more pure metal solid products with a higher potential for recycling. ${ }^{4}$

For hydrometallurgical applications of sulfate or sulfur reduction, addition of an electron donor to the process is needed as the streams lack organic compounds. ${ }^{20,23,24}$ Sulfate requires eight electrons for reduction to sulfide (eq 2), resulting in the consumption of fairly large amounts of organic bulk chemicals or inorganic $\mathrm{H}_{2}$. This constitutes a large share of the operational costs, which limits the industrial application of sulfate reduction. ${ }^{25}$

$$
\mathrm{SO}_{4}^{2-}+10 \mathrm{H}^{+}+8 \mathrm{e}^{-} \rightarrow \mathrm{H}_{2} \mathrm{~S}+4 \mathrm{H}_{2} \mathrm{O}
$$

By metabolizing elemental sulfur, a stoichiometric fourfold decrease in the electron donor consumption is achieved compared the sulfate reduction (eq 3). ${ }^{25,26}$ Thus, reduction of elemental sulfur under low $\mathrm{pH}$ and high temperature conditions could potentially improve the economy and widen the scope of application of biological sulfide generation technologies.

$$
\mathrm{S}^{0}+2 \mathrm{H}^{+}+2 \mathrm{e}^{-} \rightarrow \mathrm{H}_{2} \mathrm{~S}
$$

However, the start-up of industrial sulfur-reducing bioreactors would require large amounts of microbial inoculation material. Anaerobic granulation reactors for treatment of industrial wastewaters are widespread, for example, in the paper and food processing industries, ${ }^{27}$ and therefore granular sludge from such reactors is widely available. Granular sludge from such reactors has a high microbial diversity and has been used previously as an inoculum for successful start-up of methanogenic and sulfate-reducing laboratory-scale bioreactors at (hyper)thermophilic conditions. ${ }^{14,28,29}$ We hypothesized that anaerobic sludges might also serve as a suitable inoculation material for sulfur reduction at hyperthermoacidophilic conditions in bioreactors at the laboratory, pilot, and full scale.

In this study, we screened three granular sludges originating from industrial bioreactors treating wastewater, for assessing elemental sulfur-reducing activity at $\mathrm{pH} 4.0$ and high temperature $\left(70-80{ }^{\circ} \mathrm{C}\right)$. Two of the granular sludges were further examined at $\mathrm{pH}$ 2.0-3.5. The most active sludge was used to inoculate a $4 \mathrm{~L}$ gas-lift bioreactor, which was operated in semibatch mode for 97 days at $\mathrm{pH} 3.5$ and $80{ }^{\circ} \mathrm{C}$.

\section{MATERIALS AND METHODS}

2.1. Origin of Sludges and Precultivation. The sludges of three industrial anaerobic full-scale reactors operated at mesophilic temperature conditions and circumneutral $\mathrm{pH}$ were used as the inoculum in our experiments. These sludges are referred to as Emmen, Eerbeek, and Lenzing. The Emmen sludge was granular and originated from a sulfate-reducing bioreactor with low methane production at the company Emmtec, located in Emmen, the Netherlands. This bioreactor is of the upflow anaerobic sludge blanket (UASB) type and is fed with ethanol as the sole electron donor and carbon source. $^{30}$ Eerbeek granular sludge originated from a UASB bioreactor at the company Industriewater Eerbeek, located in Eerbeek, the Netherlands, treating waste water from paper mills. Sludge from this reactor has been analyzed previously for its microbial composition. ${ }^{31,32}$ Lenzing granular sludge came from a bioreactor from the company Lenzing, located in Lenzing, Austria, which is fed with a viscose factory wastewater containing complex COD and sulfate. ${ }^{33}$ The sludges were stored at $4{ }^{\circ} \mathrm{C}$ until use.

The medium composition for batch experiments was (in $\mathrm{mM}): \mathrm{CaCl}_{2} \cdot 2 \mathrm{H}_{2} 0,0.75 ; \mathrm{KH}_{2} \mathrm{PO}_{4}, 3.01 ;\left(\mathrm{NH}_{4}\right)_{2} \mathrm{SO}_{4}, 2.8$; $\mathrm{NaCl}$, 5.13; $\mathrm{MgSO}_{4} \cdot 7 \mathrm{H}_{2} \mathrm{O}, 0.49$; and $0.1 \mathrm{~g} \cdot \mathrm{L}^{-1} \mathrm{BBL}$ yeast extract. A trace element solution $(1 \mathrm{~mL}$ per liter of culture medium) was also added which contained (in $\mathrm{mM}$ ): $\mathrm{ZnSO}_{4}$. $7 \mathrm{H}_{2} \mathrm{O}, 3.48 ; \mathrm{CuSO}_{4} \cdot 5 \mathrm{H}_{2} \mathrm{O}, 8.01 ; \mathrm{MnSO}_{4} \cdot \mathrm{H}_{2} \mathrm{O}, 5.92$; $\mathrm{NaMoO}_{4} \cdot 2 \mathrm{H}_{2} \mathrm{O}, 2.28 ; \mathrm{CoCl}_{2} \cdot 6 \mathrm{H}_{2} \mathrm{O}, 2.47 ; \mathrm{SeO}_{2}$, 5.74; $\mathrm{H}_{3} \mathrm{BO}_{4}, 1$; and $\mathrm{NiCl}_{2} \cdot 6 \mathrm{H}_{2} \mathrm{O}, 4.21$. The $\mathrm{pH}$ of the medium was adjusted to $4.0 \pm 0.1$ using sulfuric acid. Prior to inoculation, bottles with the medium were flushed with nitrogen gas $\left(\mathrm{O}_{2}<0.5\right.$ ppmv, Linde Gas Benelux B.V., the Netherlands) during $20 \mathrm{~min}$ per liter of medium with a gas flow rate of $25 \mathrm{~mL} \cdot \mathrm{s}^{-1}$. The medium was then distributed over $250 \mathrm{~mL}$ batch bottles, with $150 \mathrm{~mL}$ of medium per bottle and $190 \mathrm{mg}$ of elemental sulfur $\left(1.3 \mathrm{~g} \cdot \mathrm{L}^{-1}\right)$. Five grams of wet sludge were added for inoculation, the $\mathrm{pH}$ was corrected to the intended value for study, and the bottles were inserted in an anaerobic hood and left overnight. The subsequent day the electron donor was added and the bottles were closed with butyl stoppers. The following electron donors were tested independently: methanol ( $5 \mathrm{mM})$, ethanol $(5 \mathrm{mM})$, acetate (5 $\mathrm{mM})$, formate $(5 \mathrm{mM})$, glucose $(5 \mathrm{mM})$, and $\mathrm{H}_{2}(80$ vol \% in headspace). After the addition of the electron donor, the headspace of the bottles was flushed with $\mathrm{N}_{2}$ and $\mathrm{CO}_{2}$ in a ratio 80:20 (vol \%), except for the bottles containing $\mathrm{H}_{2}$ as the electron donor, which replaced nitrogen. Control experiments were done with bottles following the aforementioned procedure with the corresponding modifications: without electron donor, without elemental sulfur, and with formaldehyde addition $\left(500 \mathrm{mg} \cdot \mathrm{L}^{-1}\right)$ for microbial inhibition. The bottles were incubated at 70 and $80{ }^{\circ} \mathrm{C}$ in an orbital incubated shaker at $160 \mathrm{rpm}$. From the bottles with sulfide production, suspended solids were recovered from the whole bottle after 25 days by centrifuging at $3620 \mathrm{~g}$ for $30 \mathrm{~min}$. The pellet was transferred to $250 \mathrm{~mL}$ bottles with $125 \mathrm{~mL}$ fresh medium with $\mathrm{pH} 3.5 \pm 0.1$, and the bottles were incubated with the same electron donor and at the same temperature. For each subsequent transfer the $\mathrm{pH}$ was lowered by 0.5 units, down to $\mathrm{pH} 2.0 \pm 0.1$. Batch experiments were performed in duplicate.

Microbiological produced sulfur has shown to promote microbial growth, ${ }^{21}$ for elemental sulfur used in experiments originated from a full-scale sulfide oxidizing bioreactor treating biogas of a food waste digester. Soluble impurities in sulfur were removed through multiple 2:1 extractions with demineralized water. The sulfur-water mixture was agitated for $2 \mathrm{~min}$ and sulfur was recovered by centrifugation at $3620 \mathrm{~g}$ for $10 \mathrm{~min}$. The resulting pellet was resuspended with demineralized water and the procedure repeated until the suspension reached a conductivity $\leq 20 \mu \mathrm{S} \cdot \mathrm{cm}^{-1}$ after which the suspension was dried for $12 \mathrm{~h}$ at $105{ }^{\circ} \mathrm{C}$. The resulting solid was ground and sieved to a particle size $\leq 200 \mu \mathrm{m}$.

2.2. Electron Donor Mass Balance. To determine the electron donor conversion, two batch bottles were inoculated using hydrogen as the electron donor following the aforementioned procedure at a $\mathrm{pH}$ of 3.5. Once prepared and sealed, the headspace of the bottles was replaced with a combination of $\mathrm{N}_{2}$ and $\mathrm{CO}_{2}$ 80:20 (vol \%). Hydrogen gas (5 $\mathrm{mL}$ ) was injected into the bottles and then incubated at $80^{\circ} \mathrm{C}$. Daily liquid and gas samples were taken at normal temperature for sulfide analysis and hydrogen composition analysis, 


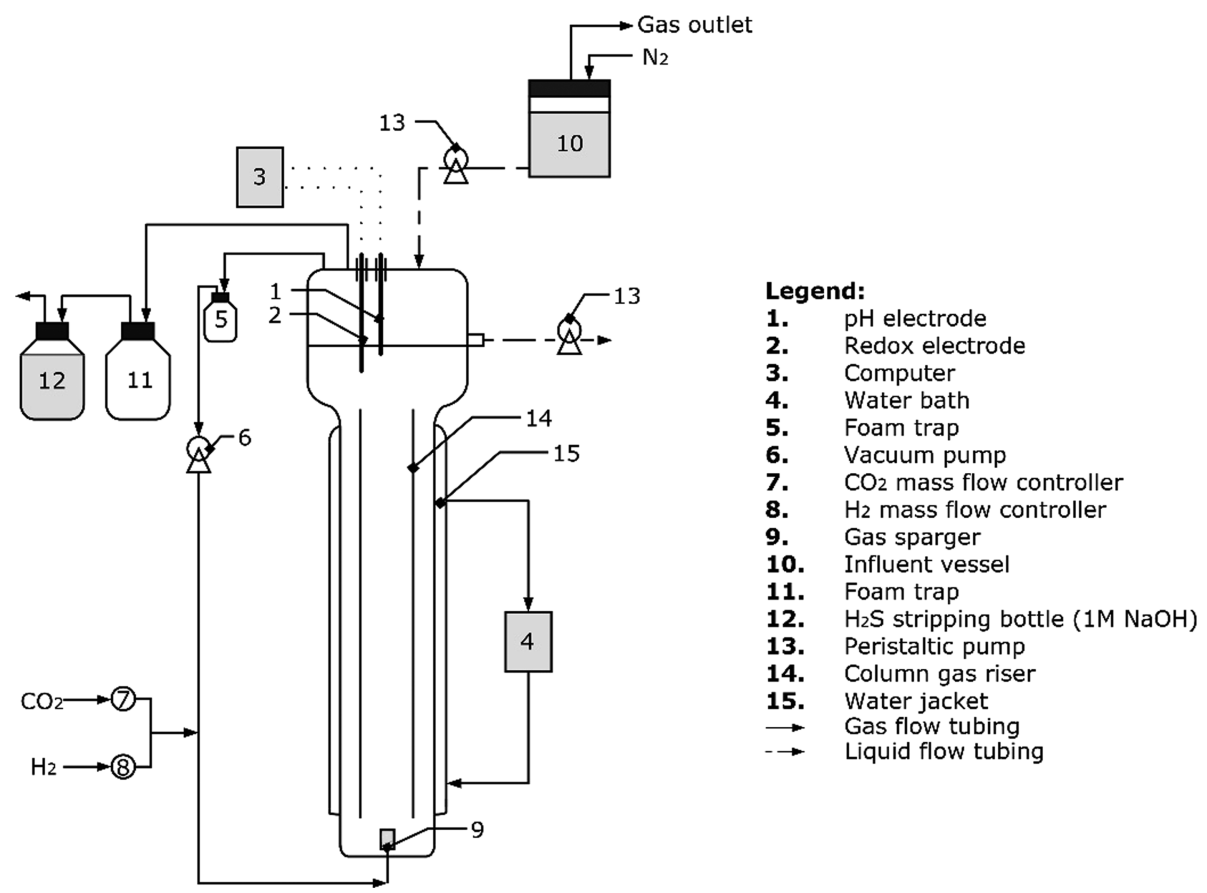

Figure 1. Scheme of the gas-lift bioreactor with $\mathrm{H}_{2} \mathrm{~S}$ stripping in the outlet gas.

respectively. Internal bottle pressure was determined for gas mass calculations. After all the initial hydrogen was consumed, an additional $5 \mathrm{~mL}$ of hydrogen was injected into the bottles and the analysis procedure repeated.

2.3. Gas-Lift Reactor Inoculation and Operation. A glass gas-lift reactor with a working volume of $4 \mathrm{~L}$ (Figure 1) was used for a larger scale experiment on hyperthermoacidophilic sulfur reduction with $\mathrm{H}_{2}$ as the electron donor and $\mathrm{CO}_{2}$ as the carbon source. The temperature of the reactor was maintained at $80{ }^{\circ} \mathrm{C}$ with a water jacket heated with a Julabo F32-HL heater (Julabo, Seelbach, Germany), and the $\mathrm{pH}$ in the reactor was controlled at 3.5 using $1 \mathrm{M}$ sulfuric acid. The reactor was inoculated with $15 \mathrm{~g} \cdot \mathrm{L}^{-1}$ of wet Emmen sludge, and elemental sulfur (41 grams, dry weight) was suspended in $50 \mathrm{~mL}$ anaerobic demineralized water and supplied to the reactor through a feed port. The reactor was operated in a semibatch mode by replacing $1 \mathrm{~L}$ of reactor solution by fresh medium every 8 days to ensure sufficient supply of nutrients. Additional sulfur was supplied regularly, aiming to maintain a sulfur concentration of at least $10 \mathrm{~g} \cdot \mathrm{L}^{-1}$. Sulfur has a tendency to accumulate as a foam layer above the water-gas interface on the top of the reactor. The accumulated sulfur was regularly manually pushed back to the reactor solution with a piece of tubing. Hydrogen and carbon dioxide were supplied as the electron donor and as the carbon source, using two mass flow controllers (type El-FLOW, model FG-201CV-RAD-22-V-DA, Bronkhorst) (Veenendaal, the Netherlands) at a rate of 1.5 and $0.5 \mathrm{~L} \cdot \mathrm{h}^{-1}$ (volume at standard conditions), respectively. Enhanced gas transfer and mixing was achieved by recirculating the gas at a rate between $50-80 \mathrm{~L} \cdot \mathrm{h}^{-1}$ using a vacuum pump KNF Neuberger type N820.3FT.18 (Freiburg, Germany). Gas and liquid flow tubing and connections were made from PTFE (Schott A.G, Mainz, Germany and Serto A.G, Fuldabrück, Germany). The redox potential and $\mathrm{pH}$ were continuously measured with a Prosense QP181X-TJ/Ag/ $\mathrm{AgCl} / 12 \times 250 \mathrm{~mm}$ glass electrode.
During the first 67 days of operation, a $\mathrm{H}_{2} \mathrm{~S}$ absorption solution was installed in the recycle gas line. However, this led to inefficient scrubbing and an underestimation of sulfide production. Therefore, on day 67 the configuration was changed as shown in Figure 1, with absorption of $\mathrm{H}_{2} \mathrm{~S}$ from the effluent gas in a $2 \mathrm{M} \mathrm{NaOH}$ solution, after which sulfide production could be monitored effectively.

2.4. Chemical Analyses. Samples for sulfide analysis were diluted in a solution containing $1 \mathrm{mM} \mathrm{NaOH}$ and $0.1 \mathrm{mM}$ zinc acetate for sulfide fixation. Dissolved sulfide was analyzed using a Hach Lange kit LCK-653 (Hach, Germany) which is based on the reaction of sulfide with dimethyl-p-phenylenediamine and ferric chloride. The absorption was measured in a spectrophotometer DR3900 (Hach, Germany). Sulfate was measured by ion chromatography on a Dionex ICS 2100 equipped with an IonPac AS19 column $(4 \times 2550 \mathrm{~mm})$ (Dionex, USA) eluted at $30{ }^{\circ} \mathrm{C}$ with potassium hydroxide (5 $\left.\mathrm{mM}, 1 \mathrm{~mL} \cdot \mathrm{min}^{-1}\right)$.

The headspace composition of the batch bottles was analyzed with gas chromatography (Shimadzu GC-2010 series) equipped with two columns in parallel, a Porabond Q $(50 \mathrm{~m} \times$ $0.53 \mathrm{~mm})$ and Molsieve $5 \mathrm{~A}(25 \mathrm{~m} \times 0.53 \mathrm{~mm})$ for nitrogen, oxygen, and methane. Hydrogen analysis was carried out with a Hewlett Packard GC-5890 series equipped with a CP-Molsieve $5 \mathrm{~A}$ column $(30 \mathrm{~m} \times 0.53 \mathrm{~mm})$. Acetate, propionate, butyrate, methanol, and ethanol were measured with a GC system Agilent $7890 \mathrm{~B}$ equipped with an HP-FFAP column $(25 \mathrm{~m} \times$ $0.32 \mathrm{~mm}$ ). Formate was analyzed with an HPLC system Ultimate 3000 (Thermo Fisher, USA) equipped with an Alltech OA-1000 column $(300 \mathrm{~mm} \times 6.5 \mathrm{~mm})$ (Hichrom, UK) eluted at $60{ }^{\circ} \mathrm{C}$ with sulfuric acid $(1.25 \mathrm{mM}, 0.6 \mathrm{~mL}$. $\min ^{-1}$ ).

2.5. Statistical Analysis. The sulfide data here presented was analyzed with a chi-square test for normality followed by an analysis of variance (ANOVA) for the establishment of significant differences. The ANOVA single factor was calculated using an $\alpha$-value of 0.05 for the data clustered in 

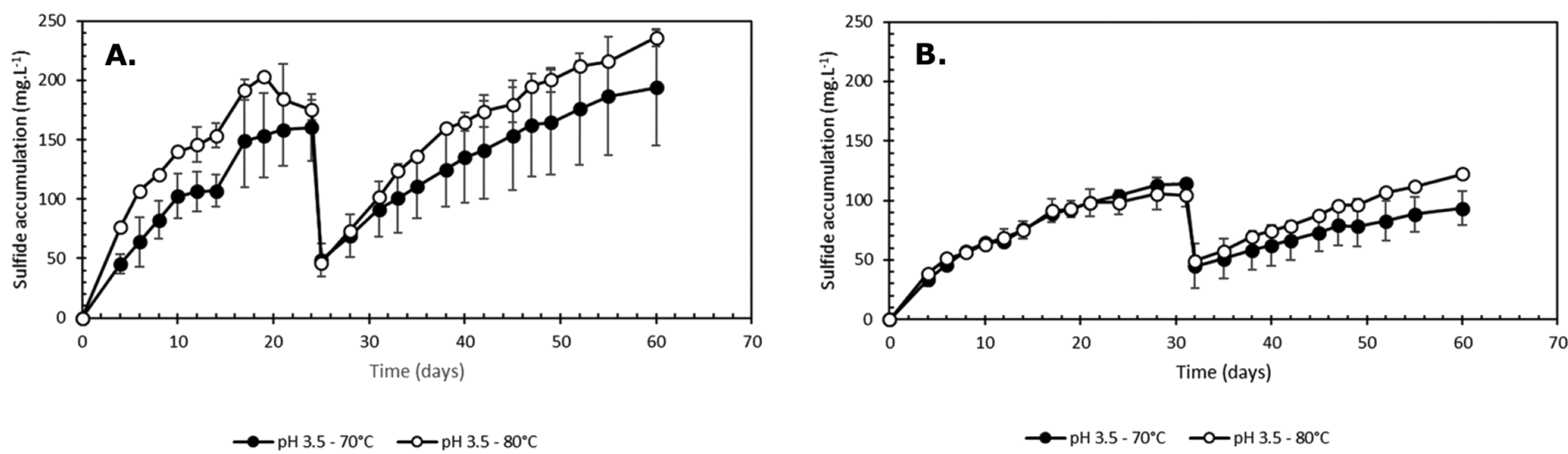

Figure 2. Figures A and B show the dissolved sulfide concentrations of the Emmen and Eerbeek sludges, respectively. The cultures were incubated using $\mathrm{H}_{2}$ as the electron donor at $70{ }^{\circ} \mathrm{C}$ (filled markers) and $80{ }^{\circ} \mathrm{C}$ (empty markers) and $\mathrm{pH} 3.5$. On day 24 and 31 the headspace of the bottles was flushed with $\mathrm{H}_{2} / \mathrm{CO}_{2}$ (80:20 vol \%). Data markers represent average values of duplicates and error bars show the standard deviation.

three groups: (1) the sludge origin and temperature; (2) the sludge origin and $\mathrm{pH}$; and $(3) \mathrm{pH}$ and temperature. The differences in data sets discussed here lie within the framework of this analysis.

\section{RESULTS AND DISCUSSION}

3.1. Screening of Anaerobic Sludges for SulfurReducing Activity at Initial pH 4.0 and 70 and $80{ }^{\circ} \mathrm{C}$. Anaerobic sludges from three full-scale bioreactors, at mesophilic conditions, treating industrial wastewaters were screened for elemental sulfur-reducing activity at $\mathrm{pH} 4.0$ and temperatures of 70 and $80{ }^{\circ} \mathrm{C}$. Less than $2 \mathrm{mg} \cdot \mathrm{L}^{-1}$ sulfide was found after 60 days incubation with methanol, ethanol, acetate, formate, and glucose with the three sludges, showing that these organic compounds did not support sulfur reduction in our experimental setup. Microbial activity controls with the three sludges at $30{ }^{\circ} \mathrm{C}$ yielded sulfide using methanol, ethanol, and hydrogen (Supporting Information, Table S1). However, mesophilic conditions were not the focus of this study and were therefore not further investigated. In bottles with Emmen, Eerbeek, and Lenzing sludges incubated with $\mathrm{H}_{2}$ (80 vol \%) as the electron donor and $\mathrm{CO}_{2}(20 \mathrm{vol} \%)$ as the carbon source, $>50 \mathrm{mg} \cdot \mathrm{L}^{-1}$ sulfide was produced within 18 days (data not shown). Chemical controls without addition of sludge but with added elemental sulfur, biological controls with sludge but without added elemental sulfur, and biological controls with added elemental sulfur and inactivated sludge (with $500 \mathrm{mg}$. $\mathrm{L}^{-1}$ of formaldehyde) all showed $<1 \mathrm{mg} \cdot \mathrm{L}^{-1}$ sulfide accumulation, after 60 days of incubation.

The biological control experiment without sulfur confirmed that sulfide was not formed through the reduction of sulfate, which was present in the medium at a concentration of around $450 \mathrm{mg} \cdot \mathrm{L}^{-1}$ due to addition of sulfuric acid for $\mathrm{pH}$ adjustment. The sulfate concentration remained constant $\left( \pm 20 \mathrm{mg} \cdot \mathrm{L}^{-1}\right)$ during incubation, providing further evidence that sulfate reduction did not account for sulfidogenesis. Biological disproportionation of sulfur to sulfide and sulfate ${ }^{34}$ could also be excluded as the sulfide and sulfate concentrations did not increase without $\mathrm{H}_{2}$ but with sulfur and sludge (results not shown). Furthermore, in the biological controls where formaldehyde $\left(500 \mathrm{mg} \cdot \mathrm{L}^{-1}\right)$ for microbial inactivation was added, sulfide remained below $1 \mathrm{mg} \cdot \mathrm{L}^{-1}$ for 80 days, revealing the biological nature of sulfidogenesis. Additionally, in the incubations generating up to $100 \mathrm{mg}$ of dissolved and gaseous sulfide per L of medium (calculated using eq.4), an increase of
$100 \mathrm{mg} \cdot \mathrm{L}^{-1}$ of sulfate would be expected based on biological sulfur disproportionation. For the same reason, chemical sulfur disproportionation (also called sulfur hydrolysis), reported to occur at temperatures above $80^{\circ} \mathrm{C}$ and elevated pressures, ${ }^{35,36}$ could therefore be excluded. Formate, acetate, propionate, and butyrate concentrations remained below $5 \mathrm{mg} \cdot \mathrm{L}^{-1}$ in incubations with $\mathrm{H}_{2} / \mathrm{CO}_{2}$.

Thus, sulfide formation in the bottles with Emmen, Lenzing, and Eerbeek sludge could be unambiguously attributed to sulfur reduction with $\mathrm{H}_{2}$ as the electron donor at hyperthermoacidophilic conditions. The substrates, besides sulfate, on which these sludges were cultivated in their respective fullscale reactors, were ethanol (Emmen), paper mill wastewater (Eerbeek), and viscose factory wastewater (Lenzing). The finding that microorganisms from anaerobic sludges grown on a wide range of substrates show sulfur-reducing activity at hyperthermoacidophilic conditions suggests that this characteristic is fairly widespread among such sludges.

3.2. Sulfur-Reducing Activity of Pre-Exposed Emmen and Eerbeek Sludge at Initial pH 3.5 and 70 and $80^{\circ} \mathrm{C}$. The Emmen and Eerbeek sludges yielded the highest sulfide production rate and maximum sulfide concentration in the

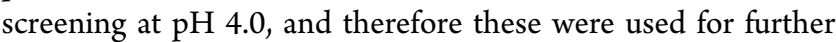
study. The Emmen and Eerbeek sludge from the $\mathrm{pH} 4.0$ incubations with $\mathrm{H}_{2} / \mathrm{CO}_{2}$ at 70 and $80{ }^{\circ} \mathrm{C}$ was transferred to fresh medium with $\mathrm{pH} 3.5$ and then incubated at the same temperature. Control incubations at $\mathrm{pH} 3.5$ yielded less than 1 $\mathrm{mg} \cdot \mathrm{L}^{-1}$ of sulfide.

Sulfide production at $\mathrm{pH} 3.5$ followed a typical concave pattern in all incubations, leveling off with increasing sulfide concentration (Figure 2A,B). However, the obtained sulfide production rate and the maximum sulfide concentration were clearly different for the two sludges. For the Emmen sludge incubations, $100 \mathrm{mg} \cdot \mathrm{L}^{-1}$ of sulfide was generated within 6 and 10 days at 70 and $80{ }^{\circ} \mathrm{C}$, respectively. At both 70 and $80^{\circ} \mathrm{C}$, the Eerbeek sludge incubations reached $100 \mathrm{mg} \cdot \mathrm{L}^{-1}$ of sulfide. Also, the maximum sulfide concentration reached in the incubations differed for both sludges. While Emmen sludges reached $150-200 \mathrm{mg} \cdot \mathrm{L}^{-1}$ after $17-24$ days at both temperatures, Eerbeek sludge reached $100-120 \mathrm{mg} \cdot \mathrm{L}^{-1}$ at both temperatures after $21-31$ days.

Temperature did not affect sulfidogenesis with the Eerbeek sludge, while with Emmen sludge the sulfide formation rate was approximately $1 / 3$ less at $70{ }^{\circ} \mathrm{C}$ compared to that at 80 

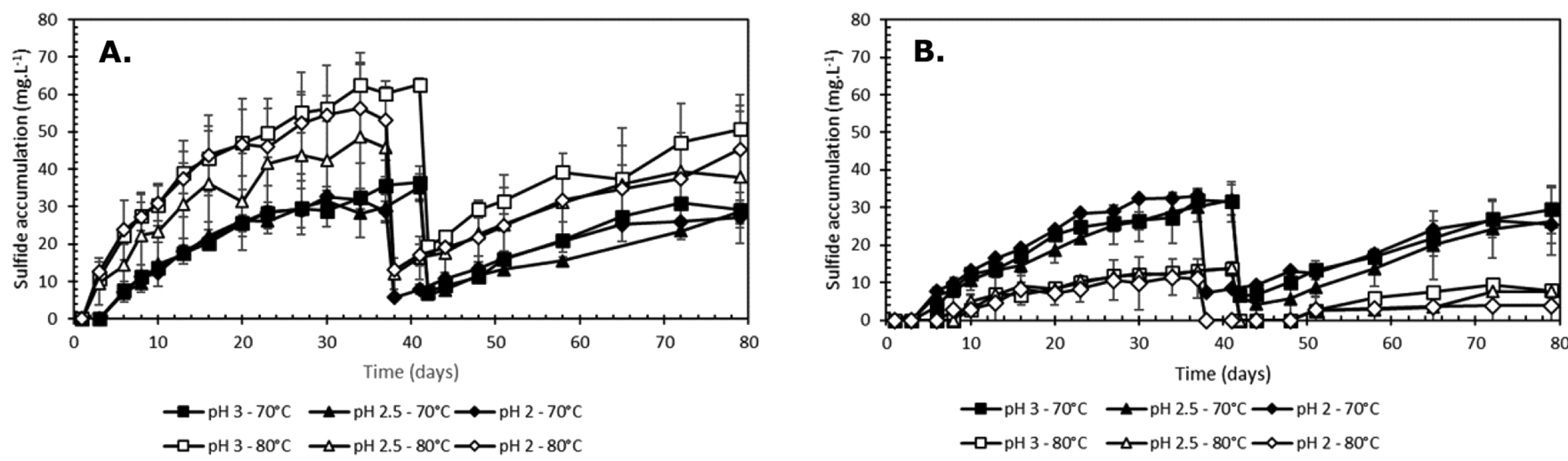

Figure 3. Figures $\mathrm{A}$ and $\mathrm{B}$ show the dissolved sulfide concentrations of the Emmen and Eerbeek sludges, respectively. On day 39 and 41 the headspace of the bottles was flushed with $\mathrm{H}_{2} / \mathrm{CO}_{2}(80: 20 \mathrm{vol} \%)$. Data markers represent average values of duplicates and error bars show the standard deviation.

${ }^{\circ} \mathrm{C}$. The results reveal that both sludges have sulfur-reducing activity at $70-80{ }^{\circ} \mathrm{C}$ and $\mathrm{pH} 3.5$.

3.3. Inhibition by $\mathrm{H}_{2} \mathrm{~S}$ at $\mathrm{pH}$ 3.5. Both Emmen and Eerbeek sludges showed a progressive decrease in the sulfide production until the sulfide concentration reached a maximum (Figure 2A,B). To assess if sulfide toxicity was the cause of the inhibition, $\mathrm{H}_{2} \mathrm{~S}$ was removed by flushing the headspace of the bottles with $\mathrm{H}_{2} / \mathrm{CO}_{2}$ (80:20 vol \%) on day 24 for Emmen sludge and day 31 for Eerbeek sludge. Sulfide production resumed immediately after, indicating that sulfide at a concentration of $150-200 \mathrm{mg} \cdot \mathrm{L}^{-1}$ (Emmen) and $100-120$ $\mathrm{mg} \cdot \mathrm{L}^{-1}$ (Eerbeek) was indeed inhibitory. At $\mathrm{pH} 3.5$ and lower, $>99.9 \%$ of sulfide is present as the undissociated $\mathrm{H}_{2} \mathrm{~S}$ species. ${ }^{37}$ It has been suggested that the $\mathrm{H}_{2} \mathrm{~S}$ species is the most toxic for microbial life as this uncharged molecule presumably easily permeates the lipid cell membrane. ${ }^{5}$ The inhibitory $\mathrm{H}_{2} \mathrm{~S}$ concentrations of $100-200 \mathrm{mg} \cdot \mathrm{L}^{-1}$ found here for the sulfurreducing microorganisms in the sludges lie within the range found for other anaerobic microorganisms. ${ }^{38}$ Also, in the period after flushing, a progressive decrease of sulfidogenesis was found with both sludges. However, with the Emmen sludge, sulfide accumulated to a higher concentration of 200$240 \mathrm{mg} \cdot \mathrm{L}^{-1}$ than the maximum level found previously. Presumably, the microbial community was able to adapt to a certain extent to sulfide, or the slight increase of the $\mathrm{pH}$ from 3.4 to 3.5-3.6 during the experiment (Supporting Information, Figure S1) favored the activity of the microorganisms. After flushing, the Eerbeek sludge reached a higher sulfide concentration only at $70{ }^{\circ} \mathrm{C}$, with a $\mathrm{pH}$ increase from 3.5 to 3.7 from the start until the end of the experiment. Inhibition by hydrogen depletion was discarded because $>33 \mathrm{mM}$ hydrogen remained in the headspace of the bottles at the end of each cycle.

3.4. Sulfur-Reducing Activity of Emmen and Eerbeek Sludges at Initial pH 2.0-3.0 and 70 and $80{ }^{\circ} \mathrm{C}$. The potential of the sludges for hyperthermoacidophilic sulfur reduction at $\mathrm{pH}$ below 3.5 was further explored. To this purpose, sludge from the incubations at $\mathrm{pH} 3.5$ was recovered, transferred to medium with $\mathrm{pH} 3.0$, and incubated at the corresponding temperature. This procedure was consequently repeated to $\mathrm{pH} 2.5$ and 2.0. Control incubations yielded less than $1 \mathrm{mg} \cdot \mathrm{L}^{-1}$ of sulfide once again.

At $\mathrm{pH} 3.0$ and lower, sulfidogenesis still proceeded, although at lower rates than at $\mathrm{pH} 3.5$ (Figure 3), for both sludges and at both temperatures. The Emmen sludge had a 5.8-fold reduction in the sulfide producing rates at $\mathrm{pH}$ 2.0-3.0 relative to that at $\mathrm{pH}$ 3.5. Sulfidogenesis rates of the Eerbeek sludge had a nine and threefold decrease at 80 and $70{ }^{\circ} \mathrm{C}$, respectively, compared to the ones at $\mathrm{pH}$ 3.5. Also, the maximum sulfide concentrations were much lower, but these concentrations were still inhibitory, as revealed by the resumption of sulfidogenesis after flushing. In addition to the differences between the results obtained at $\mathrm{pH} 3.5$ and $\mathrm{pH} 2.0$ / $2.5 / 3.0$, there were still clear differences in the sulfidogenesis rate and maximum sulfide concentration for the two sludges in the $\mathrm{pH}$ range $2.0-3.0$. For the incubations with the Emmen sludge, the maximum sulfide concentrations were $40-60 \mathrm{mg}$. $\mathrm{L}^{-1}$ at $\mathrm{pH} 2.0-3.0$ and $80{ }^{\circ} \mathrm{C}$, while at $70{ }^{\circ} \mathrm{C}$ the maximum sulfide concentrations were $30-35 \mathrm{mg} \cdot \mathrm{L}^{-1}$. Incubations with the Eerbeek sludge reached sulfide levels of around $30 \mathrm{mg} \cdot \mathrm{L}^{-1}$ at $\mathrm{pH} 2.0-3.0$ and $70{ }^{\circ} \mathrm{C}$, while at $80^{\circ} \mathrm{C}$ the maximum level was $10-14 \mathrm{mg} \cdot \mathrm{L}^{-1}$.

Acidophilic organisms reportedly have an internal $\mathrm{pH}$ between 4.6 and $7 .{ }^{39}$ To maintain the intracellular $\mathrm{pH}$ of the cell, extreme acidophilic microorganisms (optimal $\mathrm{pH}<3$ ) have developed homeostatic self-regulatory systems, ${ }^{39}$ such as inverting the membrane potential (Donnan potential) to avoid a proton influx to the cytoplasm. Moderate acidophiles $(\mathrm{pH}$ optimum around 5) might not use this strategy. ${ }^{39}$ The observed lower sulfide reducing rates under more acidic conditions, point toward a consortium composed by moderate acidophiles or acidotolerant microorganisms rather than extreme acidophiles.

Because $>99.9 \%$ of sulfide species exists as $\mathrm{H}_{2} \mathrm{~S}$ below $\mathrm{pH}$ 3.5 , sulfide is not expected to be more inhibitory at $\mathrm{pH} 2.0$ than at a $\mathrm{pH}$ of 3.5. However, at more acidic conditions the toxic effect of hydrogen sulfide could have added up to the increased energy investment to pump the proton influx out the cytoplasm. Thus, in addition to inhibition due to sulfide, inhibition by protons seems to have played a role as well.

3.5. High Temperature and Low pH Sulfur Reduction with $\mathrm{H}_{2}$ as the Electron Donor in a Gas-Lift Reactor. A 4 $\mathrm{L}$ gas-lift reactor was inoculated with $15 \mathrm{~g} \cdot \mathrm{L}^{-1}$ wet weight Emmen sludge. Hydrogen and carbon dioxide were supplied as the electron donor and carbon source, respectively, and elemental sulfur as the electron acceptor (starting and maintained around $10 \mathrm{~g} \cdot \mathrm{L}^{-1}$ ). Gas-lift reactors are effective for transfer of $\mathrm{H}_{2}$ to growth media in biological high-rate reactors. ${ }^{40,41}$ 


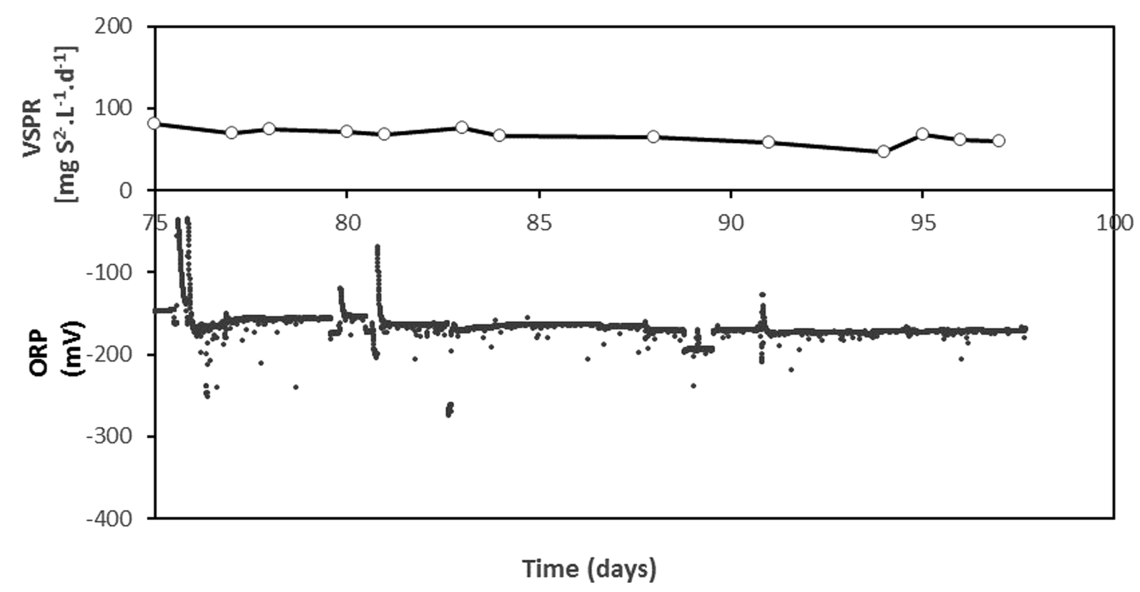

Figure 4. Volumetric sulfide production rate (VSPR) and ORP measured with an on-line electrode in the sulfur-reducing gas-lift reactor at $\mathrm{pH} 3.5$ and $80{ }^{\circ} \mathrm{C}$. Rates until day $0-67$ were inaccurate due to incomplete scrubbing of $\mathrm{H}_{2} \mathrm{~S}$ (see also Section 2), therefore these data are omitted.

The gas-lift reactor was operated at $80{ }^{\circ} \mathrm{C}$ and $\mathrm{pH} 3.5$, conditions at which relatively high sulfide production and production rates were observed with the Emmen sludge in the batch experiments. During the first 67 days of the experiment, sulfide production was monitored by regular analysis of the sulfide accumulation in the scrubber solution installed in the recycle gas line. This gave an underestimation of the sulfide production, as the scrubbing efficiency rapidly declined due to $\mathrm{CO}_{2}$ absorption (data not shown). After day 67, the scrubber solution was placed in the outlet gas line (as shown in Figure 1) after which $\mathrm{H}_{2} \mathrm{~S}$ scrubbing was effective, indicated by the absence of sulfide in the effluent gas. Sulfide production in the gas-lift reactor was measured within 1 day after start-up. From day 0 to $67, \mathrm{H}_{2} \mathrm{~S}$ was absorbed from the large recycle gas, keeping the sulfide concentration in the reactor medium low at 0.68-1.53 $\mathrm{mg} \cdot \mathrm{L}^{-1}$. After day 67, sulfide was no longer absorbed from the recycle gas, resulting in increased sulfide concentrations in the reactor of around $5 \mathrm{mg} \cdot \mathrm{L}^{-1}$. In order not to limit sulfur reduction by substrate limitation, the reactor was fed with an excess of $\mathrm{H}_{2} / \mathrm{CO}_{2}$. Due to stripping of $\mathrm{H}_{2} \mathrm{~S}$ from the reactor medium, this also kept the sulfide concentration far below the inhibitory level of $\geq 200 \mathrm{mg} \cdot \mathrm{L}^{-1}$ observed in the batch experiments. The oxidation-reduction potential (ORP) of the reactor solution after day 67 normally varied between -153 and $-185 \mathrm{mV}$ (Figure 4). The granules of the inoculum gradually disintegrated during the experiment.

Although the results clearly reveal that stable sulfur reduction is possible under the hyperthermoacidophilic conditions tested, the volumetric rate was still fairly low compared to other microbial sulfidogenesis processes at milder conditions. For sulfur and sulfate reduction processes at moderate conditions ( $\mathrm{pH} 5-7$, temperature $30{ }^{\circ} \mathrm{C}$ ), volumetric sulfide production rates up to $1.3 \mathrm{~g} \cdot \mathrm{L}^{-1} \cdot \mathrm{d}^{-1}$ (gaslift $)^{13}$ and $10 \mathrm{~g} \cdot \mathrm{L}^{-1} \cdot \mathrm{d}^{-1}(\mathrm{CSRT})^{42}$ have been reported. Thus, to become relevant for application, the sulfide production rate under hyperthermoacidophilic conditions $\left(60-80 \mathrm{mg} \cdot \mathrm{L}^{-1} \cdot \mathrm{d}^{-1}\right)$ needs to be increased by one to two orders of magnitude. Hydrogen transfer can be ruled out as the limiting factor as this will not occur in gas-lift reactors up to conversion rates of at least $10 \mathrm{~g} \cdot \mathrm{L}^{-1} \cdot \mathrm{d}^{-1}$. 41

Because sulfur is a solid with a low solubility of $122 \mu \mathrm{g} \mathrm{S} \cdot \mathrm{L}^{-1}$ at $80{ }^{\circ} \mathrm{C},{ }^{43}$ substrate bioavailability or the rate of dissolution may also represent a limitation to the process. Strong indications exist that dissolved polysulfides represent the actual terminal electron acceptors in sulfur-reducing processes at mesophilic/neutrophilic conditions. ${ }^{13,16}$ However, under acidophilic conditions polysulfides are unstable and split in $\mathrm{H}_{2} \mathrm{~S}$ and elemental sulfur, resulting in extremely low polysulfide concentrations in the order of $10^{-11} \mathrm{~mole} \cdot \mathrm{L}^{-1}$ at pH 3.0, $1 \mathrm{mM} \mathrm{H}_{2} \mathrm{~S}$ and an excess of elemental sulfur. ${ }^{43-45}$ It has been suggested that nanosized sulfur particles formed from this reaction represent the terminal electron acceptor. ${ }^{46,47}$ However, also other mechanisms for sulfur bioavailability have been proposed, yet it is not elucidated which mechanism is prevailing. ${ }^{47}$ In any case, the mechanism of sulfur bioavailability in the reactor may have constituted a limitation for the process rate. For instance, diffusion of sulfur nanoparticles could also represent a rate-limiting step.

3.6. No Methanogenesis and Acetogenesis during Sulfur Reduction at Hyperthermophilic Conditions. Methane was not detected $(<1 \%)$ in the head space of the batch incubations at $\mathrm{pH}$ 2.0-4.0, and also in the reactor methane was not detected in the outlet gas. In additional batch experiments with sludge and $\mathrm{H}_{2} / \mathrm{CO}_{2}$, but no added elemental sulfur, also no methane was found. This indicated that methanogens present in the inoculum sludge were inhibited under hyperthermoacidophilic conditions. Although the methanogenic sludge from mesophilic origin has been used successfully to inoculate methanogenic reactors operated at (hyper)thermophilic conditions, ${ }^{28,29}$ the $\mathrm{pH}$ of the medium in these reactors was circumneutral. Also, no hydrogenotrophic methanogens have been found in mixed or pure cultures to date that can grow under the hyperthermoacidophilic conditions applied in our experiments. Moreover, no acetate, propionate, or butyrate was detected $\left(<1 \mathrm{mg} \cdot \mathrm{L}^{-1}\right)$ in the incubations and the reactor. Thus, sulfur reduction at thermoacidophilic conditions with $\mathrm{H}_{2}$ in the reactor took place with little or no formation of side products, suggesting that a high selectivity is possible with the process.

Another potential metabolism which could have occurred at the operating conditions could have been acetogenesis. Acetogenic microorganisms can convert $\mathrm{H}_{2}$ and $\mathrm{CO}_{2}$ via the acetyl-coA pathway mostly generating acetate. Nonetheless, no acetate (nor propionate or butyrate) was detected in the incubations. With over 100 acetogenic species isolated to date, acetogens present high taxonomic and genetic diversity. ${ }^{48}$ Microorganisms able to perform acetogenesis at high temperature are well known such as Clostridium thermoaceticum or 
Moorella thermoacetica. ${ }^{49}$ However, no descriptions under low $\mathrm{pH}$ or hyperthermoacidophile microorganisms have been reported to the best of our knowledge.

A microbial community analysis would be of interest to clarify the discussion presented here and increase certainty. We performed several trials for DNA extraction for such analysis, yet interferences with the minerals originated from the sludge, and the low biomass concentration in the system yielded low DNA concentrations necessary for this analysis. We are currently addressing these issues and intend to provide this information in future work.

\section{ASSOCIATED CONTENT}

\section{(s) Supporting Information}

The Supporting Information is available free of charge at https://pubs.acs.org/doi/10.1021/acs.est.0c02557.

Dissolved sulfide accumulation in the screening stage, change in $\mathrm{pH}$ during the incubation, hydrogen and sulfide mass balance in a batch system inoculated with Emmen sludge, total sulfide calculations, and electron donor mass balance (PDF)

\section{AUTHOR INFORMATION}

\section{Corresponding Author}

Jan Weijma - Department of Environmental Technology, Wageningen University \& Research, Wageningen 6708 WG, the Netherlands; Email: jan.weijma@wur.nl

\section{Authors}

Adrian Hidalgo-Ulloa - Department of Environmental Technology, Wageningen University \& Research, Wageningen 6708 WG, the Netherlands; $\odot$ orcid.org/0000-0003-01886678

Irene Sánchez-Andrea - Laboratory of Microbiology, Wageningen University \& Research, Wageningen 6708 WE, the Netherlands

Cees Buisman - Department of Environmental Technology, Wageningen University \& Research, Wageningen 6708 WG, the Netherlands

Complete contact information is available at: https://pubs.acs.org/10.1021/acs.est.0c02557

\section{Notes}

The authors declare no competing financial interest.

\section{ACKNOWLEDGMENTS}

This work is part of the research program STW with project number 14979, which is financed by the Dutch Research Council (NWO). The authors declare no competing financial interest. We thank H. Dijkman and F. Stams for valuable discussions on the research presented here.

\section{REFERENCES}

(1) Kieu, H. T. Q.; Müller, E.; Horn, H. Heavy metal removal in anaerobic semi-continuous stirred tank reactors by a consortium of sulfate-reducing bacteria. Water Res. 2011, 45, 3863-3870.

(2) Nancucheo, I.; Johnson, D. B. Selective removal of transition metals from acidic mine waters by novel consortia of acidophilic sulfidogenic bacteria. Microb. Biotechnol. 2012, 5, 34-44.

(3) van Houten, B. H. G. W.; van Doesburg, W.; Dijkman, H.; Copini, C.; Smidt, H.; Stams, A. J. M. Long-term performance and microbial community analysis of a full-scale synthesis gas fed reactor treating sulfate- and zinc-rich wastewater. Appl. Microbiol. Biotechnol. 2009, 84, 555-563.

(4) Sánchez-Andrea, I.; Sanz, J. L.; Bijmans, M. F. M.; Stams, A. J. M. Sulfate reduction at low $\mathrm{pH}$ to remediate acid mine drainage. $J$. Hazard. Mater. 2014, 269, 98-109.

(5) Bijmans, M. F. M.; de Vries, E.; Yang, C.-H.; Buisman, C. J. N.; Lens, P. N. L.; Dopson, M. Sulfate reduction at $\mathrm{pH} 4.0$ for treatment of process and wastewaters. Biotechnol. Prog. 2010, 26, 1029-1037.

(6) Bijmans, M. F. M. Sulfate reduction under acidic conditions for selective metals recovery. Doctoral thesis, Wageningen University, Wageningen, NL, 2008.

(7) Yildiz, M.; Yilmaz, T.; Arzum, C. S.; Yurtsever, A.; Kaksonen, A. H.; Ucar, D. Sulfate reduction in acetate- and ethanol-fed bioreactors: Acidic mine drainage treatment and selective metal recovery. Miner. Eng. 2019, 133, 52-59.

(8) Hol, A. Bio-reduction of sulfide minerals to recover invisible gold. Doctoral thesis, Wageningen University, Wageningen, NL, 2011.

(9) Lopes, S. I. D. C. Sulfate reduction at low $\mathrm{pH}$ in organic wastewaters. Doctoral thesis, Wageningen University, Wageningen, NL, 2007.

(10) Muyzer, G.; Stams, A. J. M. The ecology and biotechnology of sulphate-reducing bacteria. Nat. Rev. Microbiol. 2008, 6, 441-454.

(11) Moodley, I.; Sheridan, C. M.; Kappelmeyer, U.; Akcil, A. Environmentally sustainable acid mine drainage remediation: Research developments with a focus on waste/by-products. Miner. Eng. 2018, 126, 207-220.

(12) Canganella, F.; Wiegel, J. Anaerobic Thermophiles. Life 2014, 4, 77-104.

(13) Sun, R.; Zhang, L.; Zhang, Z.; Chen, G. H.; Jiang, F. Realizing high-rate sulfur reduction under sulfate-rich conditions in a biological sulfide production system to treat metal-laden wastewater deficient in organic matter. Water Res. 2018, 131, 239-245.

(14) Vallero, M. V. G.; Camarero, E.; Lettinga, G.; Lens, P. N. L. Thermophilic $\left(55-65{ }^{\circ} \mathrm{C}\right)$ and Extreme Thermophilic $\left(70-80{ }^{\circ} \mathrm{C}\right)$ Sulfate Reduction in Methanol and Formate-Fed UASB Reactors. Biotechnol. Prog. 2004, 20, 1382-1392.

(15) Sánchez-Andrea, I.; Stams, A. J. M.; Weijma, J.; Contreras, P. G.; Dijkman, H.; Rozendal, R. A.; Johnson, D. B. A case in support of implementing innovative bio-processes in the metal mining industry. FEMS Microbiol. Lett. 2016, 363, 1-4.

(16) Zhang, L.; Zhang, Z.; Sun, R.; Liang, S.; Chen, G.-H.; Jiang, F. Self-accelerating sulfur reduction via polysulfide to realize a high-rate sulfidogenic reactor for wastewater treatment. Water Res. 2018, 130, $161-167$.

(17) Zhang, L.; Lin, X.; Zhang, Z.; Chen, G.-H.; Jiang, F. Elemental sulfur as an electron acceptor for organic matter removal in a new high-rate anaerobic biological wastewater treatment process. Chem. Eng. J. 2018, 331, 16-22.

(18) Guo, J.; Wang, J.; Qiu, Y.; Sun, J.; Jiang, F. Realizing a high-rate sulfidogenic reactor driven by sulfur-reducing bacteria with organic substrate dosage minimization and cost-effectiveness maximization. Chemosphere 2019, 236, 124381.

(19) Fischer, F.; Zillig, W.; Stetter, K. O.; Schreiber, G. Chemolithoautotrophic metabolism of anaerobic extremely thermophilic archaebacteria. Lett. Nat. 1983, 301, 511-513.

(20) Brimblecombe, P., The Global Sulfur Cycle. In Treatise on Geochemistry, Second ed.; Elsevier: 2013; 10, 559-591.

(21) Florentino, A. P.; Weijma, J.; Stams, A. J. M.; Sánchez-Andrea, I. Sulfur Reduction in Acid Rock Drainage Environments. Environ. Sci. Technol. 2015, 49, 11746-11755.

(22) Lewis, A. E. Review of metal sulphide precipitation. Hydrometallurgy 2010, 104, 222-234.

(23) Nancucheo, I.; Hedrich, S.; Johnson, D. B. New microbiological strategies that enable the selective recovery and recycling of metals from acid mine drainage and mine process waters. Mineral. Mag. 2012, 76, 2683-2692.

(24) Qiu, Y. Y.; Guo, J. H.; Zhang, L.; Chen, G. H.; Jiang, F. A highrate sulfidogenic process based on elemental sulfur reduction: Cost- 
effectiveness evaluation and microbial community analysis. Biochem. Eng. J. 2017, 128, 26-32.

(25) Florentino, A. P.; Weijma, J.; Stams, A. J. M.; Sánchez-Andrea, I., Ecophysiology and Application of Acidophilic Sulfur-Reducing Microorganisms. In Biotechnology of Extremophiles, Grand Challenges in Biology and Biotechnology, Springer International Publishing Switzerland: 2016; 1, 141-175.

(26) Searcy, D. G. Elemental sulfur reduction to H2S by Tetrahymena thermophila. Eur. J. Protistol. 2018, 62, 56-68.

(27) Lettinga, G. Anaerobic digestion and wastewater treatment systems. Antonie van Leeuwenhoek 1995, 67, 3-28.

(28) van Lier, J. B.; Groeneveld, N.; Lettinga, G. Development of thermophilic methanogenic sludge in compartmentalized upflow reactors. Biotechnol. Bioeng. 1996, 50, 115-124.

(29) Tähti, H.; Kaparaju, P.; Rintala, J. Hydrogen and methane production in extreme thermophilic conditions in two-stage (upflow anaerobic sludge bed) UASB reactor system. Int. J. Hydrogen Energy 2013, 38, 4997-5002.

(30) Hulshoff, L. W.; Lens, P. N. L.; Weijma, J.; Stams, A. J. M. New developments in reactor and process technology for sulfate reduction. Water Sci. Technol. 2001, 44, 67-76.

(31) Roest, K.; Heilig, H. G. H. J.; Smidt, H.; de Vos, W. M.; Stams, A. J. M.; Akkermans, A. D. L. Community analysis of a full-scale anaerobic bioreactor treating paper mill wastewater. Syst. Appl. Microbiol. 2005, 28, 175-185.

(32) Oude Elferink, S. J. W. H.; Vorstman, W. J. C.; Sopjes, A.; Stams, A. J. M. Characterization of the sulfate-reducing and syntrophic population in granular sludge from a full-scale anaerobic reactor treating papermill wastewater. FEMS Microbiol. Ecol. 1998, 27, 185-194.

(33) Möbius, C. H.; Demel, I.; Schmid, A.; Temper, U.; Carozzi, A.; Buisman, C.; Weijma, J.; Rijnaarts, H. H. M.; Hendrickx, T. L. G.; Brockmann, M., Anwendung für organisch und anorganisch belastete Abwässer anderer Industriebereiche. In Anaerobtechnik, Rosenwinkel, K.-H.; Kroiss, H.; Dichtl, N.; Seyfried, C.-F.; Weiland, P., Eds. Springer: Berlin, 2015; 541-601.

(34) Amenabar, M. J.; Boyd, E. S. Mechanisms of Mineral Substrate Acquisition in a Thermoacidophile. Appl. Environ. Microbiol. 2018, 84, e00334-e00318.

(35) Fang, H.; Brown, B.; Young, D.; Nešić, S. In Investigation of Elemental Sulfur Corrosion Mechanisms, NACE Corrosion conference \& Expo, Houston, Texas, USA 13-17 March 2011, 2011; Houston, Texas, USA 2011.

(36) Smith, J. W. Isotopic fractionations accompanying sulfur hydrolysis. Geochem. J. 2000, 34, 95-99.

(37) Rochelle, G. T.; Chang, H. T.; Chakravarti, S. Research needs for acid gas kinetics and equilibria in alkanolamine systems. Final report, ; Gas Research Institute: Chicago, 1991.

(38) Paulo, L. M.; Stams, A. J. M.; Sousa, D. Z. Methanogens, sulphate and heavy metals: a complex system. Rev. Environ. Sci. Biotechnol. 2015, 14, 537-553.

(39) Baker-Austin, C.; Dopson, M. Life in acid: $\mathrm{pH}$ homeostasis in acidophiles. Trends Microbiol. 2007, 15, 165-171.

(40) Weijma, J.; Gubbels, F.; Hulshoff Pol, L. W.; Stams, A. J. M.; Lens, P.; Lettinga, G. Competition for $\mathrm{H} 2$ between sulfate reducers, methanogens and homoacetogens in a gas-lift reactor. Water Sci. Technol. 2002, 45, 75-80.

(41) Van Houten, R. T.; Pol, L. W. H.; Lettinga, G. Biological sulphate reduction using gas-lift reactors fed with hydrogen and carbon dioxide as energy and carbon source. Biotechnol. Bioeng. 1994, 44, 586-594.

(42) Bijmans, M. F.; Dopson, M.; Ennin, F.; Lens, P. N.; Buisman, C. J. Effect of sulfide removal on sulfate reduction at $\mathrm{pH} 5$ in a hydrogen fed gas-lift bioreactor. J. Microbiol. Biotechnol. 2008, 18, $1809-1818$.

(43) Kamyshny, A. Solubility of cyclooctasulfur in pure water and sea water at different temperatures. Geochim. Cosmochim. Acta 2009, $73,6022-6028$.
(44) Schauder, R.; Müller, E. Polysulfide as a possible substrate for sulfur-reducing bacteria. Arch. Microbiol. 1993, 160, 377-382.

(45) Kamyshny, A.; Gun, J.; Rizkov, D.; Voitsekovski, T.; Lev, O. Equilibrium distribution of polysulfide ions in aqueous solutions at different temperatures by rapid single phase derivatization. Environ. Sci. Technol. 2007, 41, 2395-2400.

(46) Boyd, E. S.; Druschel, G. K. Involvement of intermediate sulfur species in biological reduction of elemental sulfur under acidic, hydrothermal conditions. Appl. Environ. Microbiol. 2013, 79, 20612068.

(47) Florentino, A. P.; Pereira, I. A. C.; Boeren, S.; van den Born, M.; Stams, A. J. M.; Sánchez-Andrea, I. Insight into the sulfur metabolism of Desulfurella amilsii by differential proteomics. Environ. Microbiol. 2019, 21, 209-225.

(48) Drake, H. L.; Gößner, A. S.; Daniel, S. L. Old acetogens, new light. Ann. N. Y. Acad. Sci. 2008, 1125, 100-128.

(49) Drake, H. L.; Daniel, S. L. Physiology of the thermophilic acetogen Moorella thermoacetica. Res. Microbiol. 2004, 155, 869-883. 